\title{
Polycyclic aromatic hydrocarbons and organochlorine pesticides in rice hull from a typical e-waste recycling area in southeast China: temporal trend, source, and exposure assessment
}

\author{
Fang Liu $\cdot$ Chunyang Liao $\cdot$ Jianjie Fu \\ Jungang Lv $\cdot$ Qinzhao Xue $\cdot$ Guibin Jiang
}

Received: 1 October 2012/Accepted: 25 March 2013/Published online: 4 April 2013

(C) Springer Science+Business Media Dordrecht 2013

\begin{abstract}
The residue levels of 16 US EPA priority polycyclic aromatic hydrocarbons (PAHs) and 16 selected organochlorine pesticides (OCPs) in rice and rice hull collected from a typical e-waste recycling area in southeast China were investigated from 2005 to 2007. PAHs and OCPs also were measured in ten mollusk species (soft tissues) collected in an adjacent bay in 2007. Individual PAHs were frequently found in the entire sample set (including the rice, hull, and mollusk samples) with a detection rate of $73 \%$. The total concentrations of 16 PAHs ( $\mathrm{PAHs}$ ) and 16 OCPs ( $\Sigma$ OCPs) were in the range of $40.8-432 \mathrm{ng} / \mathrm{g}$ dry weight (mean: $171 \mathrm{ng} / \mathrm{g}$ ) and $2.35-925 \mathrm{ng} / \mathrm{g}$ (122 ng/g), respectively, which were comparable or higher than those reported in some polluted areas. Statistical comparisons suggested that the concentrations of contaminants in hull gradually decreased from 2005 to 2007 and the residue levels were generally in
\end{abstract}

F. Liu · C. Liao $(\bowtie) \cdot$ Q. Xue

Key Laboratory of Coastal Zone Environmental Processes, Yantai Institute of Coastal Zone Research (YIC), Chinese Academy of Sciences (CAS), Shandong Provincial Key Laboratory of Coastal Zone

Environmental Processes, YICCAS, Yantai 264003,

Shandong, China

e-mail: cyliao@yic.ac.cn

C. Liao $\cdot$ J. Fu $\cdot$ J. Lv $\cdot$ G. Jiang

State Key Laboratory of Environmental Chemistry and Ecotoxicology, Research Center for Eco-Environmental Sciences, Chinese Academy of Sciences, P.O. Box 2871, Beijing 100085, China the order of mollusk, hull, and rice, on a dry weight basis. Principal component analysis in combination with diagnostic ratios implied that combustion of coal, wood, and plastic wastes that are closely associated with crude e-waste recycling activities is the main source of PAHs. The finding of decreasing trend of concentrations of PAHs in this area is consistent with the efforts of local authorities to strengthen regulations on illegal e-waste recycling activities. Composition analysis suggested that there is a recent usage or discharge of hexachlorocyclohexane and dichlorodiphenyltrichloroethane into the tested area. The estimated daily intake (EDI) of $\Sigma$ PAHs and $\Sigma$ OCPs (calculated from mean concentrations) through rice and mollusk consumption was 0.411 and $0.921 \mu \mathrm{g} / \mathrm{kg}$ body weight (bw)/day, respectively.

Keywords E-waste $\cdot$ Rice hull $\cdot$ Mollusk $\cdot$ PAHs · OCPs $\cdot$ Temporal trend

\section{Introduction}

Developing countries in East and South Asia, such as China, India, and Pakistan, have became important sites for electronic waste (e-waste) recycling recently (Osibanjo and Nnorom 2007). It is estimated that approximately $70 \%$ of e-waste generated worldwide is processed in China every year (Robinson 2009). Due to lack of relevant standardized rules, the 
processing of e-wastes in China is usually conducted in illegal workshops or open yards mainly based on the crude techniques such as sorting, firing, incineration, and acidic washing. The illegal and unsafe e-waste dismantling activities have induced serious environmental and health problems in surrounding areas. Abundant contaminants, for example, polychlorinated dibenzo- $p$-dioxins and dibenzo-furans ( $\mathrm{PCDD} / \mathrm{Fs}$ ), polycyclic aromatic hydrocarbons (PAHs), polychlorinated biphenyls (PCBs), polybrominated diphenyl ethers (PBDEs), and heavy metals, were released accompanying with the unregulated dismantling activities (Ma et al. 2009; Liu et al. 2008b; Fu et al. 2008, 2012).

PAHs, a class of organic compounds that consist of two or more fused aromatic rings, are produced in incomplete combustion or pyrolysis of organic matter and during various industrial processes (Liu et al. 2008a; Douben 2003). In general, PAHs occur in complex mixtures and they may consist of hundreds of compounds. Concern about PAHs is growing because some of them have been identified as carcinogenic, mutagenic, and teratogenic (Douben 2003). PAHs are ubiquitous in the environment and also are found in a wide range of foodstuffs, such as vegetables, meat, fish, and cereals (EC 2002; EFSA 2008). Human is exposed to PAHs by various sources, and diet is considered an important pathway (EC 2002; EFSA 2008).

Agriculture production still plays a critical role in the national economy of China, and a large scale of pesticides were produced and used in China for many decades (Nakata et al. 2002; Tao et al. 2008). Zhejiang province, with a very dense population located in southeast China, holds intensively managed agricultural systems, and many organochlorine pesticides (OCPs) such as hexachlorocyclohexane ( $\mathrm{HCH})$, dichlorodiphenyltrichloroethane (DDT), and hexachlorobenzene (HCB) have extensively been used in this area for many years, which causes relatively higher residue levels of pesticides although the use of some highly toxic chemicals has been reduced or withdrawn recently (Gao et al. 2006). Summary data from the Food and Agriculture Organization (FAO 2004) show that rice approximately accounts for $30 \%$ of the dietary energy supply and $20 \%$ of the dietary protein intake around the world. Rice is a staple foodstuff for daily consumption in China, particularly in southern China including Zhejiang province, and investigation on the residue levels of OCPs in rice planted in this area is thus of great interest.

Studies on occurrence and distribution of persistent organic pollutants (POPs) in multiple matrices, including air, dust, water, sediment, soil, fish, human hair, blood, and milk, in e-waste recycling area are increasingly growing ( $\mathrm{Li}$ et al. 2007; Wong et al. 2007; Zhao et al. 2007; Huo et al. 2007; Shen et al. 2009). However, information about contamination levels of POPs in rice collected from e-waste recycling area is limited. In this study, rice samples (Oryza sativa L.) were consecutively collected from Taizhou, Zhejiang province, a typical e-waste recycling area in southeast China for 3 years (2005-2007) to examine the residue levels of PAHs and OCPs. Meanwhile, mollusk samples also were collected from an adjacent bay in 2007 to analyze the accumulation of these pollutants, and their contamination profiles and possible sources were compared. Based on the mean concentrations measured in the rice and mollusk samples, the potential dietary exposure doses of PAHs and OCPs from rice and mollusk were estimated.

\section{Materials and methods}

Site description and sampling

Taizhou (E121. $\left.2^{\circ}, \mathrm{N} 28.3^{\circ}\right)$, a coastal city covering an area of around $9,400 \mathrm{~km}^{2}$ with a population of more than 5.5 million in Zhejiang province, southeast China, possesses a great deal of novel industrial and commercial enterprises. Since 1990s, this region has being rapidly developed as one of the most important e-waste recycling centers in China which contributes to regional economic development but also poses a serious threat to local environment because of unregulated dismantling activities (Hicks et al. 2005). Contamination of organic pollutants, such as PCDD/ Fs, PBDEs, PCBs, and polybrominated biphenyls (PBBs), as well as heavy metals in rice samples collected from Taizhou region have been reported in recent years (Fu et al. 2008, 2012; Zhao et al. 2009, 2010, 2011; Xing et al. 2010; Song et al. 2011). Taizhou is also an important place of agricultural production in Zhejiang province, and rice serves as the major crop for the local people. Thirty-three rice samples were collected directly from rice paddies which are adjacent to the recycling sites in Taizhou 
region during November and December from 2005 to 2007. Each individual rice sample was obtained by mixing at least five sub-samples from the same rice paddy. Ten mollusk samples, including Solen strictus, Corbicula formosana, Ommastrephes sp., Trachypenaeus curvirostris, Fistulobalanus albicostatus, Sepia esculenta, Ostrea gigas, Bullacta exarata, Thais clavigera, and Mactra veneriformis, were sampled from an adjacent bay in 2007, and their species were identified according to the catalog of marine mollusks in the reference book (Qi et al. 1989). All samples were immediately transferred to the laboratory and frozen at $-20{ }^{\circ} \mathrm{C}$ until processed for analysis.

Chemicals and materials

PAH standards (EPA M-610, $0.1 \mathrm{mg} / \mathrm{mL}$ in 1:1 (v/v) methanol: dichloromethane) of naphthalene (Nap), acenaphthylene (Acpy), fluorene (Flu), acenaphthene (Acp), phenanthrene (Pa), anthracene (Ant), fluoranthene $(\mathrm{Fl})$, pyrene (Pyr), benz(a)anthracene (Baa), chrysene (Chr), benzo(b)fluoranthene (Bbf), benzo(k)fluoranthene (Bkf), benzo(a)pyrene (Bap), indeno(1,2,3-cd)pyrene (Ind), dibenz(a,h)anthracene (Dba), and benzo(g,h,i)perylene (Bghip) and deuterated surrogate standards (EPA M-525-IS, $2.0 \mathrm{mg} / \mathrm{mL}$ in acetone) of $d_{10}$-acenaphthylene, $d_{12}$-chrysene, $d_{12^{-}}$ perylene, and $\mathrm{d}_{10}$-phenanthrene were purchased from AccuStandard Inc. (CT, USA). The OCP individual standards $(1,000 \mathrm{mg} / \mathrm{L}$, in acetone or methanol) were kind gifts from the Institute of Environmental Protection and Monitoring, Minister of Agriculture, China, and were mixed into one mixture standard at $10 \mu \mathrm{g} / \mathrm{mL}$ before use. All solvents used were of pesticide grade (Fisher, Germany). Florisil (60-100 mesh, Sinopharm Chemical Reagent Co. Ltd., Shanghai, China) and silica (100-200 mesh, Branch of Qingdao Haiyang Chemical Plant, Qingdao, China) were activated in oven at $150{ }^{\circ} \mathrm{C}$ for $11.5 \mathrm{~h}$ before use. Anhydrous sodium sulfate $\left(\mathrm{Na}_{2} \mathrm{SO}_{4}\right)$ was of analytical grade (Beijing Chemical Reagent Factory, Beijing, China).

Sample extraction and cleanup

The rice sample was physically separated as polished rice (here and after referred as rice) and its hull by a decorticating machine. The whole body tissues of 10-20 mollusks were dissected out by stainless steel scalpel blades or scissors, thoroughly rinsed with
Milli-Q water to eliminate extraneous impurities, and pooled together. The separated rice, hull, and tissue samples were sufficiently homogenized, freeze-dried, ground to fine powder, and sealed in polyethylene (PE) bottles. Approximately $2 \mathrm{~g}$ each of rice and $1 \mathrm{~g}$ each of hull or tissue sample were spiked with $5 \mathrm{ng}$ of the deuterated PAHs as surrogates, then extracted with

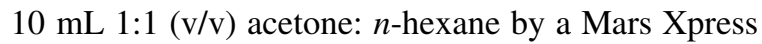
laboratory microwave oven (CEM, Matthews, NC, USA) at $600 \mathrm{~W}$ for $30 \mathrm{~min}$. The extraction processing was repeated twice. The extract was combined, concentrated to around 1-2 mL, and purified by passage through a glass column (12 mm i.d.) loaded with florisil, silica, and anhydrous $\mathrm{Na}_{2} \mathrm{SO}_{4}(2 \mathrm{~g}$ for each) from bottom to top in turn. The column was pre-

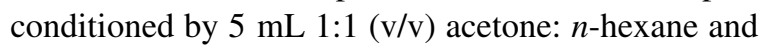

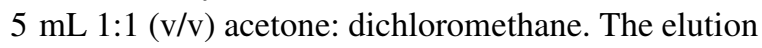
was subsequently carried out by using around $12 \mathrm{~mL}$ 1:1 (v/v) acetone: dichloromethane. The elute was concentrated to near dryness again under a gentle stream of $\mathrm{N}_{2}$, reconstituted to $0.5 \mathrm{~mL}$ with hexane, and followed by final analysis by GC-MS.

\section{Chemical analysis}

The identification and quantification of target analytes were performed by an Agilent 6890N gas chromatography (GC) coupled with an Agilent 5973N mass spectrometer (MS) operating with EI source in SIM mode (Agilent Technologies, Wilmington, DE, USA). An aliquot of sample extract $(2 \mu \mathrm{L})$ was injected with splitless mode into a DB-5MS fused silica capillary column $(30 \mathrm{~m} \times 0.25 \mathrm{~mm}$ i.d. $\times 0.25 \mu \mathrm{m}$ film thickness; J\&W Scientific, Folsom, CA, USA) with highpurity helium $(99.999 \%)$ as carrier gas at flow rate of $1.0 \mathrm{~mL} / \mathrm{min}$. The oven temperature program was $60{ }^{\circ} \mathrm{C}$ held for $2 \mathrm{~min}$, increased to $200{ }^{\circ} \mathrm{C}$ at $19{ }^{\circ} \mathrm{C} /$ min, held for $2 \mathrm{~min}$, then to $240{ }^{\circ} \mathrm{C}$ at $4.5^{\circ} \mathrm{C} / \mathrm{min}$, held for $2 \mathrm{~min}$, and finally to $290{ }^{\circ} \mathrm{C}$ at $2.5^{\circ} \mathrm{C} / \mathrm{min}$, held for $2 \mathrm{~min}$. The electron emission energy was set at $70 \mathrm{eV}$. The source temperature and quadrupole were set at 230 and $150{ }^{\circ} \mathrm{C}$, respectively.

\section{Quality control}

All appliances were rinsed by acetone and hexane before use. For every batch of 10 samples, a procedural blank was run to demonstrate freedom from contamination and a spiked sample was analyzed to 
check for the recovery of method. The limits of quantification (LOQs) ranged from $0.17 \mathrm{ng} / \mathrm{g}(\mathrm{Pa})$ to $4.68 \mathrm{ng} / \mathrm{g}(\mathrm{Dba})$ for PAHs and from $0.01 \mathrm{ng} / \mathrm{g}$ (Atrazine) to $0.05 \mathrm{ng} / \mathrm{g}(\delta-\mathrm{HCH})$ for OCPs. The matrix spike recoveries were in the range of $71-131 \%$ for PAHs and 88-120\% for OCPs. Duplicate analysis of randomly selected samples $(n=5)$ showed a coefficient variation of $<20 \%$. The average recoveries of surrogates were $72,94,102$, and $70 \%$ for $\mathrm{d}_{10^{-}}$ acenaphthylene, $\mathrm{d}_{12}$-chrysene, $\mathrm{d}_{12}$-perylene, and $\mathrm{d}_{10^{-}}$ phenanthrene, respectively. The inlet degradation of DDT was $<15 \%$ as daily checked. The regression coefficient $(r)$ of calibration standards, injected at concentrations ranging from 0.01 to $10 \mathrm{ng} / \mathrm{mL}$, was $>0.99$. A calibration curve was prepared at the beginning of analysis of every batch of 10 samples. Concentrations were quantified by the isotope dilution method based on the responses of surrogates spiked into each sample. All the concentrations were expressed as ng/g based on a dry weight basis, and moisture contents of rice and mollusk were calculated for conversion of data to wet weight basis for dietary exposure estimate.

\section{Results and discussion}

PAHs and OCPs in rice, hull, and mollusk

Sixteen PAHs listed by US EPA as priority pollutants and sixteen OCPs that have been widely used in China were examined in this study, and their concentrations in rice, hull, and mollusk samples are summarized in Table 1. Individual PAHs were frequently detected in these biological samples (containing 11 rice, 22 hulls, and 10 mollusks) with a detection rate of $73 \%$ and the concentrations of individuals ranged from 0.41 to $139 \mathrm{ng} / \mathrm{g}$ with a mean of $14.7 \mathrm{ng} / \mathrm{g}$ (Table 1). As shown in Fig. 1 and Table 1, the predominant species among the 16 PAHs were Nap, Pa, Fl, Pyr, and Ind with the concentrations ranging 0.51-92.6 (mean: 19.4), 4.96-84.2 (30.0), 3.81-86.9 (27.1), 1.68-62.6 (19.2), and 1.21-127 (19.4) ng/g, which made up in mean $12,19,14,11$, and $4 \%$ of the total concentrations of PAHs ( $\Sigma$ PAHs), respectively. The percentages of individual PAHs varied in the rice and hull samples (Fig. 1, samples 1-33), although the differences were not significant $(p>0.05$, one-way ANOVA). This suggests existence of multiple contamination sources of PAHs in the rice and hull samples. The percentages of individual PAHs in the mollusk samples varied from species to species (Fig. 1, samples 34-43), and the species differences might contribute to different accumulation pattern of PAHs. The $\Sigma$ PAHs in rice, hull, and mollusk were in the range of 40.8-138 (mean: 69.6), 67.7-412 (211), and 56.4-432 (196) ng/g, respectively. In our previous study, soil samples collected from the rice field and vicinity in the tested area have been analyzed for PAHs and the mean total concentrations of PAHs were 854 ng/g dry weight (Liao et al. 2012). The elevated concentrations of PAHs found in soil might be responsible for the relatively higher residue levels of PAHs in rice collected from Taizhou area (Tao et al. 2006). The $\Sigma$ PAH level in this study was far higher than that in rice (mean value: $2.19 \mathrm{ng} / \mathrm{g}$ fresh weight) collected from local markets of Catalonia, Spain (Perelló et al. 2009), over 2 times higher than that in hull $(95.7 \mathrm{ng} / \mathrm{g}$ dry weight) collected from a paddy field in Tianjin, one of the most heavily contaminated areas with PAHs in China (Tao et al. 2006), and lower than that in blue mussel Mytilus sp. (432 ng/g dry weight) collected from harbors in Arcachon Bay, France (Devier et al. 2005). The results indicate that serious PAH contamination exists in foodstuff in the tested area, which might be likely originated from local large-scale e-waste recycling activities.

Detectable OCPs were found in the samples with a detection rate of $30 \%$. $\gamma-\mathrm{HCH}$ (detection rate: $74 \%$ ), $o, p^{\prime}$-DDD (dichlorodiphenyldichloroethane, one metabolite of DDT; $51 \%), p, p^{\prime}$-DDD (44\%), quintozene $(79 \%)$, and dicofol $(51 \%)$ were the predominant compounds analyzed, with the concentrations ranging 7.07-223 (mean: 41.4), 1.47-139 (21.2), 0.52-567 (51.0), 0.72-51.7 (6.32), 3.48-156 (36.7) ng/g, respectively. Other OCPs were little found in the samples, and especially $\delta-\mathrm{HCH}, o, p^{\prime}$ DDE (dichlorodiphenyldichloroethylene, another metabolite of DDT), and $p, p^{\prime}$-DDE were only detected in one sample (Table 1). Concentrations of 16 OCPs ( $\sum$ OCPs) varied with two orders of magnitude among all samples, ranging from 2.35 to $925 \mathrm{ng} / \mathrm{g}$ with a mean of $122 \mathrm{ng} / \mathrm{g}$. The mean values of $\sum \mathrm{HCHs}$ (sum of $\alpha-\mathrm{HCH}, \beta-\mathrm{HCH}, \gamma-\mathrm{HCH}$, and $\delta-\mathrm{HCH}$ ) in rice and hull were 2.39 and $5.95 \mathrm{ng} /$ $\mathrm{g}$, and the corresponding values of $\sum$ DDTs (sum of $o, p^{\prime}$-DDE, $p, p^{\prime}$-DDE, $o, p^{\prime}$-DDD, $p, p^{\prime}$-DDD, $o, p^{\prime}$ DDT, and $p, p^{\prime}$-DDT) were 24.4 and $2.38 \mathrm{ng} / \mathrm{g}$, 
Table 1 Concentrations (ng/g) of PAHs and OCPs in rice, hull, and mollusk samples

\begin{tabular}{|c|c|c|c|c|c|c|}
\hline No. & Compounds & 2005 rice $\left(11^{\mathrm{a}}\right)$ & 2005 hull (12) & 2006 hull (5) & 2007 hull (5) & 2007 mollusk (10) \\
\hline 1 & Nap & $\begin{array}{l}1.27-18.1 \\
\quad(9.94 \pm 5.17)^{\mathrm{b}}\end{array}$ & $\begin{array}{l}11.4-34.2 \\
\quad(22.0 \pm 7.65)\end{array}$ & $\begin{array}{l}2.43-54.6 \\
\quad(23.7 \pm 21.1)\end{array}$ & $\begin{array}{l}0.51-6.42 \\
\quad(2.62 \pm 3.30)\end{array}$ & $\begin{array}{l}11.2-92.6 \\
(29.6 \pm 25.3)\end{array}$ \\
\hline 2 & Acpy & $<\mathrm{LOQ}$ & $<\mathrm{LOQ}$ & $<\mathrm{LOQ}$ & $<\mathrm{LOQ}$ & $\begin{array}{l}4.88-33.6 \\
\quad(14.5 \pm 13.0)\end{array}$ \\
\hline 3 & Flu & $\begin{array}{l}1.84-6.36 \\
\quad(3.68 \pm 1.67)\end{array}$ & $\begin{array}{l}2.77-6.14 \\
\quad(4.09 \pm 1.31)\end{array}$ & $1.95^{\mathrm{c}}$ & $<\mathrm{LOQ}$ & $\begin{array}{l}31.1-139 \\
\quad(72.3 \pm 46.5)\end{array}$ \\
\hline 4 & Acp & 0.57 & $<\mathrm{LOQ}$ & $<\mathrm{LOQ}$ & $<\mathrm{LOQ}$ & $\begin{array}{l}3.79-42.7 \\
\quad(15.4 \pm 18.4)\end{array}$ \\
\hline 5 & $\mathrm{~Pa}$ & $\begin{array}{l}4.96-31.8 \\
\quad(11.5 \pm 7.98)\end{array}$ & $\begin{array}{l}30.4-84.2 \\
\quad(52.5 \pm 15.4)\end{array}$ & $\begin{array}{l}16.2-36.2 \\
\quad(23.9 \pm 8.98)\end{array}$ & $\begin{array}{l}21.9-69.0 \\
\quad(46.5 \pm 20.1)\end{array}$ & $\begin{array}{l}10.5-26.8 \\
\quad(16.9 \pm 5.64)\end{array}$ \\
\hline 6 & Ant & $\begin{array}{l}1.05-5.14 \\
\quad(2.05 \pm 1.25)\end{array}$ & $\begin{array}{l}1.37-11.5 \\
\quad(5.26 \pm 3.11)\end{array}$ & $\begin{array}{l}1.32-3.58 \\
\quad(2.33 \pm 1.03)\end{array}$ & $\begin{array}{l}0.78-4.20 \\
\quad(1.91 \pm 1.39)\end{array}$ & $\begin{array}{l}0.85-19.6 \\
\quad(7.08 \pm 7.75)\end{array}$ \\
\hline 7 & $\mathrm{Fl}$ & $\begin{array}{l}4.60-16.4 \\
\quad(8.24 \pm 3.59)\end{array}$ & $\begin{array}{l}28.8-72.8 \\
\quad(49.2 \pm 14.1)\end{array}$ & $\begin{array}{l}11.9-23.6 \\
\quad(16.3 \pm 5.28)\end{array}$ & $\begin{array}{l}12.1-20.0 \\
\quad(16.4 \pm 3.44)\end{array}$ & $\begin{array}{l}3.81-86.9 \\
\quad(33.5 \pm 32.2)\end{array}$ \\
\hline 8 & Pyr & $\begin{array}{l}4.87-23.8 \\
\quad(9.03 \pm 5.40)\end{array}$ & $\begin{array}{l}23.8-62.6 \\
\quad(41.9 \pm 12.7)\end{array}$ & $\begin{array}{l}9.82-18.4 \\
\quad(13.3 \pm 4.24)\end{array}$ & $\begin{array}{l}8.23-15.4 \\
\quad(11.6 \pm 2.55)\end{array}$ & $\begin{array}{l}1.68-15.5 \\
\quad(8.75 \pm 4.18)\end{array}$ \\
\hline 9 & Baa & $\begin{array}{l}1.33-9.85 \\
\quad(3.53 \pm 2.79)\end{array}$ & $\begin{array}{l}4.17-21.9 \\
\quad(11.9 \pm 5.08)\end{array}$ & $\begin{array}{l}1.98-5.57 \\
\quad(3.68 \pm 1.63)\end{array}$ & $\begin{array}{l}2.10-2.66 \\
\quad(2.43 \pm 0.23)\end{array}$ & $\begin{array}{l}2.24-10.5 \\
\quad(4.74 \pm 2.68)\end{array}$ \\
\hline 10 & Chr & $\begin{array}{l}2.36-14.9 \\
\quad(4.64 \pm 3.63)\end{array}$ & $\begin{array}{l}24.8-65.8 \\
\quad(43.2 \pm 12.3)\end{array}$ & $\begin{array}{l}6.68-18.2 \\
\quad(11.4 \pm 4.41)\end{array}$ & $\begin{array}{l}6.93-14.2 \\
\quad(11.3 \pm 2.74)\end{array}$ & $\begin{array}{l}1.99-9.40 \\
\quad(4.37 \pm 2.28)\end{array}$ \\
\hline 11 & Bbf & $\begin{array}{l}1.47-6.93 \\
\quad(3.02 \pm 1.78)\end{array}$ & $\begin{array}{l}10.8-34.1 \\
\quad(21.5 \pm 7.77)\end{array}$ & $\begin{array}{l}5.33-13.1 \\
\quad(8.66 \pm 3.09)\end{array}$ & $\begin{array}{l}6.22-8.06 \\
\quad(7.06 \pm 0.68)\end{array}$ & $\begin{array}{l}3.59-22.8 \\
\quad(9.88 \pm 6.69)\end{array}$ \\
\hline 12 & $\mathrm{Bkf}$ & $\begin{array}{l}0.41-3.30 \\
\quad(1.25 \pm 0.76)\end{array}$ & $\begin{array}{l}4.49-12.2 \\
\quad(7.99 \pm 2.35)\end{array}$ & $\begin{array}{l}1.52-3.56 \\
\quad(2.47 \pm 0.98)\end{array}$ & $\begin{array}{l}1.73-2.09 \\
\quad(1.90 \pm 0.16)\end{array}$ & $\begin{array}{l}2.50-14.4 \\
\quad(6.33 \pm 4.14)\end{array}$ \\
\hline 13 & Bap & $\begin{array}{l}0.51-5.84 \\
\quad(2.11 \pm 1.79)\end{array}$ & $\begin{array}{l}6.16-22.8 \\
\quad(13.8 \pm 5.44)\end{array}$ & $\begin{array}{l}5.85-15.7 \\
\quad(9.49 \pm 3.88)\end{array}$ & $\begin{array}{l}5.80-11.8 \\
\quad(8.06 \pm 2.23)\end{array}$ & $\begin{array}{l}7.11-50.8 \\
\quad(22.4 \pm 15.6)\end{array}$ \\
\hline 14 & Ind & $\begin{array}{l}1.21-12.0 \\
\quad(5.89 \pm 5.13)\end{array}$ & $\begin{array}{l}4.43-19.3 \\
\quad(9.32 \pm 4.31)\end{array}$ & $\begin{array}{l}1.28-2.61 \\
\quad(1.94 \pm 0.94)\end{array}$ & 3.59 & $\begin{array}{l}117-127 \\
\quad(122 \pm 6.94)\end{array}$ \\
\hline 15 & Dba & 8.73 & 2.91 & $<\mathrm{LOQ}$ & $<\mathrm{LOQ}$ & $<\mathrm{LOQ}$ \\
\hline 16 & Bghip & $\begin{array}{l}5.28-9.44 \\
\quad(7.62 \pm 1.21)\end{array}$ & $\begin{array}{l}4.00-21.2 \\
\quad(10.6 \pm 4.57)\end{array}$ & $\begin{array}{l}1.03-7.70 \\
\quad(3.72 \pm 2.89)\end{array}$ & $\begin{array}{l}1.95-2.39 \\
\quad(2.17 \pm 0.18)\end{array}$ & $\begin{array}{l}6.68-46.2 \\
\quad(23.3 \pm 15.2)\end{array}$ \\
\hline 17 & $\alpha-\mathrm{HCH}$ & $<\mathrm{LOQ}$ & $<\mathrm{LOQ}$ & $<\mathrm{LOQ}$ & $<\mathrm{LOQ}$ & $\begin{array}{l}39.3-67.8 \\
\quad(57.8 \pm 16.0)\end{array}$ \\
\hline 18 & $\beta-\mathrm{HCH}$ & $<\mathrm{LOQ}$ & $<\mathrm{LOQ}$ & $<\mathrm{LOQ}$ & $<\mathrm{LOQ}$ & $\begin{array}{l}33.6-57.8 \\
\quad(45.0 \pm 10.0)\end{array}$ \\
\hline 19 & $\gamma-\mathrm{HCH}$ & 26.3 & $\begin{array}{l}23.0-41.1 \\
\quad(32.0 \pm 6.07)\end{array}$ & $\begin{array}{l}9.01-35.4 \\
\quad(18.5 \pm 12.6)\end{array}$ & $\begin{array}{l}7.07-12.9 \\
\quad(9.83 \pm 2.06)\end{array}$ & $\begin{array}{l}30.1-222 \\
\quad(85.8 \pm 57.5)\end{array}$ \\
\hline 20 & $\delta-\mathrm{HCH}$ & $<\mathrm{LOQ}$ & 11.9 & $<\mathrm{LOQ}$ & $<\mathrm{LOQ}$ & $<\mathrm{LOQ}$ \\
\hline 21 & $o, p^{\prime}$-DDE & $<\mathrm{LOQ}$ & $<\mathrm{LOQ}$ & $<\mathrm{LOQ}$ & $<\mathrm{LOQ}$ & 29.1 \\
\hline 22 & $p, p^{\prime}$-DDE & $<\mathrm{LOQ}$ & $<\mathrm{LOQ}$ & 1.24 & $<\mathrm{LOQ}$ & $<\mathrm{LOQ}$ \\
\hline 23 & $o, p^{\prime}$-DDD & $\begin{array}{l}1.47-6.83 \\
\quad(3.24 \pm 2.47)\end{array}$ & $\begin{array}{l}1.76-8.33 \\
\quad(5.04 \pm 4.65)\end{array}$ & $\begin{array}{l}2.50-3.74 \\
\quad(3.23 \pm 0.65)\end{array}$ & $\begin{array}{l}2.62-3.42 \\
\quad(3.06 \pm 0.30)\end{array}$ & $\begin{array}{l}2.97-139 \\
\quad(52.4 \pm 57.2)\end{array}$ \\
\hline 24 & $p, p^{\prime}$-DDD & $\begin{array}{l}0.52-4.07 \\
\quad(1.86 \pm 1.48)\end{array}$ & $\begin{array}{l}0.61-4.11 \\
\quad(1.60 \pm 1.68)\end{array}$ & $<$ LOQ & 1.83 & $\begin{array}{l}44.4-567 \\
\quad(158 \pm 203)\end{array}$ \\
\hline 25 & $o, p^{\prime}$-DDT & $\begin{array}{l}0.57-3.64 \\
\quad(1.73 \pm 1.28)\end{array}$ & $\begin{array}{l}0.66-1.36 \\
\quad(1.04 \pm 0.36)\end{array}$ & $<\mathrm{LOQ}$ & 0.57 & $\begin{array}{l}19.7-273 \\
\quad(131 \pm 98.1)\end{array}$ \\
\hline 26 & $p, p^{\prime}$-DDT & $\begin{array}{l}0.64-6.01 \\
\quad(2.98 \pm 2.02)\end{array}$ & $\begin{array}{l}0.77-1.29 \\
\quad(1.05 \pm 0.28)\end{array}$ & $<$ LOQ & $<\mathrm{LOQ}$ & $<\mathrm{LOQ}$ \\
\hline 27 & Hexachlorobenzene & $\begin{array}{l}0.26-0.40 \\
\quad(0.31 \pm 0.06)\end{array}$ & $\begin{array}{l}0.52-0.69 \\
\quad(0.59 \pm 0.08)\end{array}$ & 0.43 & $<\mathrm{LOQ}$ & $\begin{array}{l}0.50-0.96 \\
\quad(0.75 \pm 0.19)\end{array}$ \\
\hline
\end{tabular}


Table 1 continued

\begin{tabular}{|c|c|c|c|c|c|c|}
\hline No. & Compounds & 2005 rice $\left(11^{\mathrm{a}}\right)$ & 2005 hull (12) & 2006 hull (5) & 2007 hull (5) & 2007 mollusk (10) \\
\hline 28 & Atrazine & 3.91 & $\begin{array}{l}1.26-2.29 \\
\quad(1.78 \pm 0.73)\end{array}$ & $<\mathrm{LOQ}$ & 2.40 & $\begin{array}{l}3.41-17.2 \\
\quad(9.50 \pm 5.59)\end{array}$ \\
\hline 29 & Quintozene & $\begin{array}{l}2.05-8.20 \\
\quad(4.37 \pm 1.76)\end{array}$ & $\begin{array}{l}4.83-51.7 \\
\quad(10.4 \pm 13.1)\end{array}$ & $\begin{array}{l}0.72-6.67 \\
\quad(2.38 \pm 2.86)\end{array}$ & $\begin{array}{l}0.85-2.27 \\
\quad(1.28 \pm 0.60)\end{array}$ & $\begin{array}{l}8.56-11.0 \\
\quad(10.1 \pm 1.37)\end{array}$ \\
\hline 30 & Heptachlor & 111 & 2.68 & 17.7 & $<$ LOQ & $<\mathrm{LOQ}$ \\
\hline 31 & Dicofol & $\begin{array}{l}5.99-57.4 \\
\quad(31.7 \pm 36.3)\end{array}$ & $\begin{array}{l}12.6-63.8 \\
\quad(39.0 \pm 17.5)\end{array}$ & $\begin{array}{l}3.48-16.3 \\
\quad(9.91 \pm 9.09)\end{array}$ & $\begin{array}{l}12.6-25.4 \\
\quad(18.3 \pm 6.52)\end{array}$ & $\begin{array}{l}17.4-156 \\
\quad(50.9 \pm 49.1)\end{array}$ \\
\hline 32 & Chlorobenzilate & $<$ LOQ & 0.93 & $\begin{array}{l}0.95-1.94 \\
\quad(1.45 \pm 0.70)\end{array}$ & 2.48 & $\begin{array}{l}2.41-26.2 \\
\quad(7.17 \pm 8.46)\end{array}$ \\
\hline
\end{tabular}

a The number of samples

b Range (mean $\pm \mathrm{SD}$ ), ng/g

c Was only detected in one sample

respectively. The mean concentrations of $\sum \mathrm{HCHs}$ and $\sum$ DDTs in the rice and hull samples were lower than those (30 and $29 \mathrm{ng} / \mathrm{g}$ for $\sum \mathrm{HCHs} ; 31$ and $34 \mathrm{ng} / \mathrm{g}$ for $\sum$ DDTs) collected from Jiangsu province (an adjacent area of Zhejiang province) in China, with an exception of the mean concentration of $\sum \mathrm{HCHs}$ in hull, which was comparable with that reported for Jiangsu province (24.4 vs. $31 \mathrm{ng} / \mathrm{g}$; Chen et al. 2007). $\sum$ HCHs and $\sum D D T s$ in mollusks ranged below LOQ-281 (mean: 113) and 29.1-812 (218) ng/g. These mean values were far higher than those in green mussel Perna viridis L. (1.96 and
$3.62 \mathrm{ng} / \mathrm{g}$ wet weight for $\sum \mathrm{HCHs}$ and $\sum \mathrm{DDTs}$, respectively) collected during 2005-2006 from Ennore creek, Chennai, India (Sundar et al. 2010), and those in chink snail Lacuna vincta (0.21 and $0.32 \mathrm{ng} / \mathrm{g}$ wet weight) and blue mussel Mytilus edulis (0.08 and $0.12 \mathrm{ng} / \mathrm{g}$ wet weight) collected in Flatey Island, Iceland (Skarphedinsdottir et al. 2010). Zhejiang province is one of the rice production regions with a high yield in China, and the longterm large-scale usage of pesticides contributes to the serious status of OCP contamination in this area.

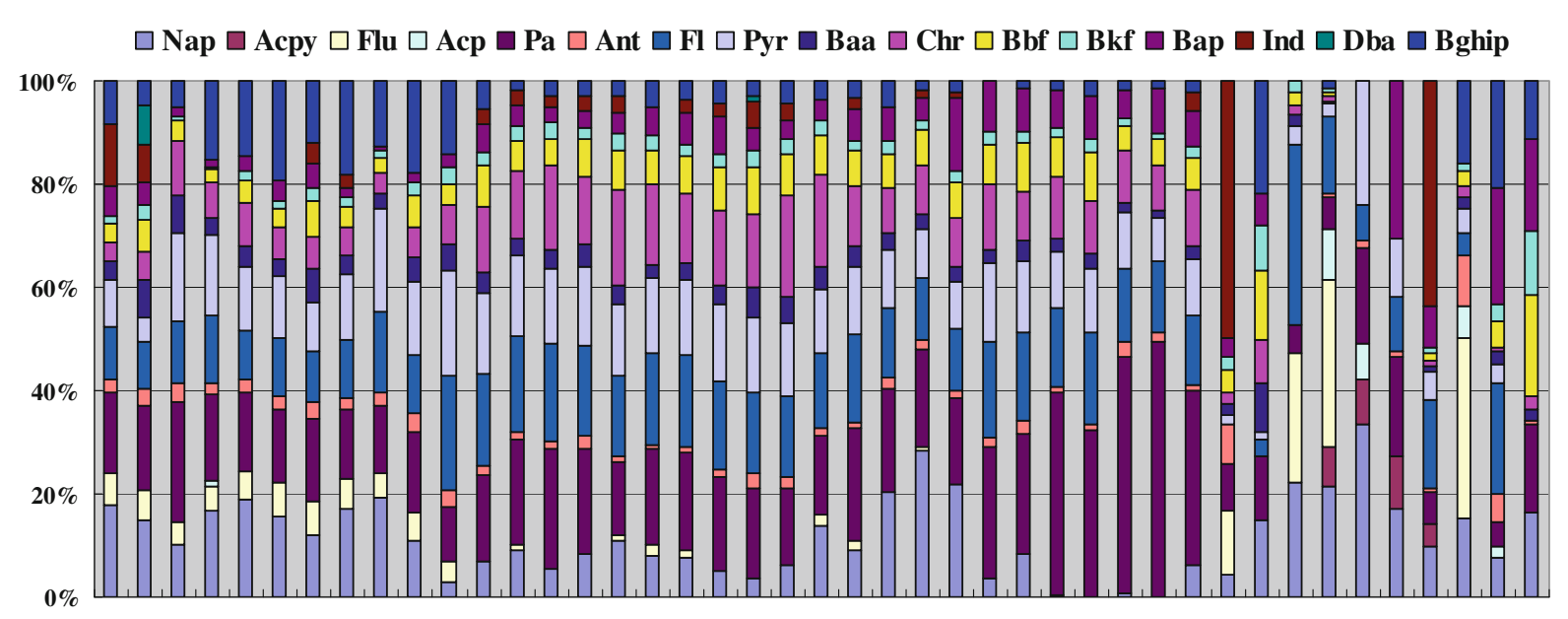

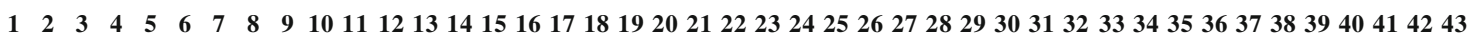

Samples

Fig. 1 Composition patterns of PAHs in rice, hull, and mollusk samples. Samples 1-11, 12-23, 24-28, 29-33, and 34-43 refer to 2005 rice, 2005 hull, 2006 hull, 2007 hull, and 2007 mollusk samples, respectively 
Temporal variations of contaminants

The contamination levels in hull are generally higher than those in rice. The mean individual concentrations of PAHs and OCPs in 2005 hull samples were, respectively, 23.3 and $16.0 \mathrm{ng} / \mathrm{g}$, which were higher than those $(5.55$ and $6.56 \mathrm{ng} / \mathrm{g})$ in 2005 rice samples (Table 1). The detection rate (52\%) of all individuals of these two groups of pollutants for 2005 hull samples was also a little higher than that $(47 \%)$ for 2005 rice samples. This might be explained by the fact that hull is outside rice and is more usually exposed to PAHs released by e-waste dismantling activities in open field as well as to OCPs in spraying process.

The mean $\Sigma \mathrm{PAH}$ and $\Sigma \mathrm{OCP}$ concentrations in each sample species (rice, hull, and mollusk) year wise are shown in Fig. 2. Temporal variations of the two classes of contaminants in the hull samples were apparent. For example, the $\Sigma \mathrm{PAH}$ concentrations in hull obviously decreased from $290 \pm 80.2 \mathrm{ng} / \mathrm{g}$ (mean $\pm \mathrm{SD}$ ) in 2005 to $112 \pm 30.3 \mathrm{ng} / \mathrm{g}$ in 2007 ( $p<0.01$, one-way ANOVA; Fig. 2). Similar trends were found for $\Sigma$ OCP concentrations in the hull samples, although the variations were not statistically significant $(p>0.05)$. As known, a large amount of e-wastes have been dismantled in Taizhou region, Zhejiang province, since 1990s (Hicks et al. 2005), and the illegal and unsafe e-waste dismantling activities have caused serious environmental pollution in this region and vicinity. More and more public concern has raised, and accordingly, the local government enacted some policies to regulate the e-waste

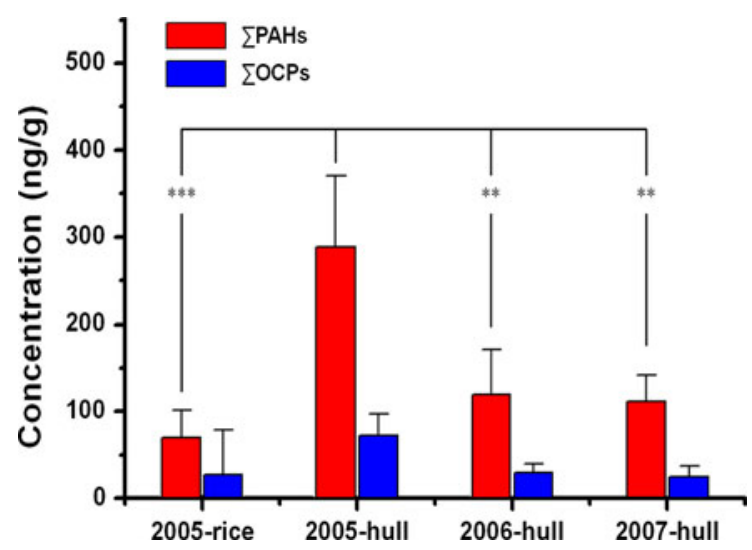

Fig. 2 The residue levels of $\sum$ PAHs and $\sum$ OCPs in rice and hull samples from 2005 to 2007 . ** $p<0.01$; *** $p<0.001$, one-way ANOVA dismantling activities in recent years (Hicks et al. 2005). Therefore, the pollution status of contaminants induced by e-waste dismantling in the tested area appears to be gradually alleviated. In the present study, comparison was made using data obtained within a span of 3 years, and so further examination is necessary after few more years to come to a concrete conclusion on the temporal variations of the contaminants studied in the present study area.

\section{Potential sources of PAHs and OCPs}

Two sources mainly contribute to PAH contamination in the environment. One is natural source which include volcanic eruptions, plant emissions, and forest fires, and another one is anthropogenic source that are mostly from the combustion of carbonaceous materials such as coals, gasoline, diesel, and other fuels (Kavouras et al. 2001). Like previous studies (Larsen and Baker 2003), principal component analysis (PCA) and diagnostic ratios were used for source apportionment of PAHs in this study. Because Acpy was not detected in rice and hull samples and Dba not in mollusk samples, a subset of 15 variables was selected for the PCA.

As for the rice and hull samples, three principal components (PCs) with eigenvalues greater than 1 were extracted, accounting for $80 \%$ of the variability in the data (Table 2). PC1, which explained $61 \%$ of the total variance, was mainly dominated by highmolecular-weight PAHs (HMW-PAHs, greater than four fused rings with molecular weight $>202$ ) such as Fl, Pyr, Baa, Chr, Bbf, Bkf, Bap, Ind. HMW-PAHs are usually originated from combustion of wood, grass, coal, gasoline, diesel, and other fuel and are regarded as representative of pyrogenic sources (Khalili et al. 1995). As mentioned above, Taizhou area has been one of the typical e-waste dismantling sites in China for a long time where various metals and chips of circuit boards were recycled through coal combustion. During the recycling, incomplete combustion of plastic wastes in crude workshops and vicinity also contributes to the PAH emissions ( $\mathrm{Yu}$ et al. 2006). Further, local rural residents in this region usually use wood and grass as fuels for daily cooking and charcoal for heating during winters. Among these individual PAHs, Pyr, Chr, and Bkf are generally associated with vehicular emissions that may be derived from the popular motorcycles in this area (Khalili et al. 1995). 
Table 2 Component loadings of PAHs

\begin{tabular}{|c|c|c|c|c|c|c|c|c|c|}
\hline \multirow[t]{2}{*}{ PAHs } & \multicolumn{3}{|c|}{ Rice and hull } & \multicolumn{6}{|l|}{ Mollusk } \\
\hline & $\mathrm{PC} 1$ & $\mathrm{PC} 2$ & PC3 & $\mathrm{PC} 1$ & $\mathrm{PC} 2$ & PC3 & PC4 & PC5 & PC6 \\
\hline Nap & 0.556 & 0.260 & 0.217 & 0.795 & 0.568 & -0.113 & -0.082 & -0.009 & 0.088 \\
\hline Acpy & $\mathrm{a}$ & a & $\mathrm{a}$ & 0.848 & 0.281 & 0.077 & -0.159 & 0.211 & -0.135 \\
\hline Flu & -0.125 & 0.808 & 0.135 & 0.714 & 0.588 & -0.123 & 0.236 & 0.016 & -0.155 \\
\hline Acp & -0.179 & 0.194 & 0.691 & 0.724 & 0.503 & -0.231 & 0.022 & 0.189 & -0.317 \\
\hline $\mathrm{Pa}$ & 0.808 & -0.318 & -0.129 & 0.294 & 0.419 & 0.697 & -0.320 & 0.311 & -0.072 \\
\hline Ant & 0.894 & 0.105 & -0.092 & -0.241 & 0.003 & -0.086 & 0.723 & 0.494 & -0.337 \\
\hline $\mathrm{Fl}$ & 0.974 & -0.109 & 0.066 & 0.539 & 0.303 & -0.223 & -0.110 & 0.212 & 0.642 \\
\hline Pyr & 0.974 & -0.062 & 0.124 & 0.695 & -0.549 & -0.065 & 0.128 & 0.121 & 0.361 \\
\hline Baa & 0.955 & 0.177 & -0.048 & -0.572 & 0.591 & -0.078 & 0.322 & -0.043 & 0.389 \\
\hline Chr & 0.952 & -0.074 & 0.078 & -0.310 & 0.760 & 0.133 & 0.375 & -0.239 & 0.235 \\
\hline Bbf & 0.984 & -0.059 & -0.017 & -0.736 & 0.537 & 0.139 & -0.293 & 0.086 & -0.078 \\
\hline $\mathrm{Bkf}$ & 0.964 & -0.009 & -0.029 & -0.706 & 0.564 & 0.141 & -0.319 & 0.055 & -0.038 \\
\hline Bap & 0.809 & -0.235 & -0.069 & -0.417 & -0.241 & -0.206 & -0.387 & 0.722 & 0.151 \\
\hline Ind & 0.819 & 0.286 & -0.178 & -0.055 & -0.150 & 0.733 & 0.442 & 0.418 & 0.195 \\
\hline Dba & 0.074 & 0.666 & -0.587 & $\mathrm{~b}$ & b & b & b & $\mathrm{b}$ & b \\
\hline Bghip & 0.673 & 0.291 & 0.422 & -0.502 & 0.240 & -0.741 & 0.049 & 0.323 & -0.027 \\
\hline Eigenvalue & 9.209 & 1.593 & 1.156 & 5.194 & 3.240 & 1.826 & 1.521 & 1.350 & 1.088 \\
\hline$\%$ Variance explained & 61.394 & 10.618 & 7.708 & 34.625 & 21.598 & 12.173 & 10.143 & 9.002 & 7.251 \\
\hline Source & Pyrogenic & Petrogenic & Unknown & Petrogenic & Pyrogenic & & Unknown & & \\
\hline
\end{tabular}

Acpy and Dba were below limit of detection in rice and hull $\left({ }^{\mathrm{a}}\right)$, and mollusk $\left({ }^{\mathrm{b}}\right)$ samples, respectively, and they thus were excluded out the PCA

PC2, which explained $11 \%$ of the total variance, was highly weighted by Flu. Flu belongs to low-molecularweight PAHs (LMW-PAHs, 2-3 fused rings), and the LMW-PAHs are more thermodynamically stable compounds mainly derived from petrogenic sources (from the release of unburned petroleum products such as gasoline, diesel oil, and fuel oil from vehicle traffics). PC3, which explained $7.7 \%$ of the total variance, was dominated by Nap, Flu, Acp, Pyr, and Bghip, representing an unknown source. The PCA results indicate that the combustion of coal, wood, and plastic wastes that are closely associated with illegal and unsafe recycling operations of e-wastes is the main sources of PAHs in this region. In addition, the vehicular emissions also contribute to the PAH contamination in some extent.

As for the mollusk samples, six PCs with eigenvalues greater than 1 were extracted, accounting for $95 \%$ of the variability in the data (Table 2). PC1, explaining $35 \%$ of the total variance, was mainly dominated by LMW-PAHs including Nap, Acpy, Flu, and Acp, representing the petrogenic sources. PC2, explaining $22 \%$ of the total variance, was mainly associated with HMW-PAHs and might be regarded as pyrogenic sources. No apparent associations between other four PCs, explaining $39 \%$ of the total variance, and individual PAHs were observed and the PCs represented unknown sources. Therefore, the PAH profile in mollusks suggests both petrogenic and pyrogenic sources.

Diagnostic ratios of PAHs, such as the ratios Fl/ (Fl + Pyr), Bap/Bghip, and HMW- to LMW-PAHs (Yunker et al. 2002; Soclo et al. 2000), can be used to identify the possible emission sources, as summarized in Table 3. The ratios of $\mathrm{Fl} /(\mathrm{Fl}+\mathrm{Pyr})$ were in range of $0.41-0.65$ with a mean 0.53 for rice and hulls and in range of $0.23-0.90$ with a mean 0.66 for mollusks, respectively. A total of $79 \%$ for rice and hulls and $63 \%$ for mollusks of the values were within the typical range for combustion-derived products. Similarly, the ratios of both Bap/Bghip and HMW- to LMW-PAHs generally fell into the ranges which are characteristic of combustion, suggesting that pyrogenic sources especially coal combustion are the 
Table 3 Diagnostic ratios of PAHs

\begin{tabular}{|c|c|c|c|c|c|c|c|}
\hline \multirow[t]{2}{*}{ Ratio } & \multirow{2}{*}{$\begin{array}{l}\text { Characteristic ratio of } \\
\text { coal combustion }\end{array}$} & \multicolumn{3}{|c|}{ Rice and hull } & \multicolumn{3}{|c|}{ Mollusk } \\
\hline & & Mean & Range & Percentage (\%) & Mean & Range & Percentage $(\%)$ \\
\hline $\mathrm{Fl} /(\mathrm{Fl}+\mathrm{Pyr})$ & $>0.5$ & 0.531 & $\begin{array}{r}0.408 \\
-0.653\end{array}$ & 78.8 & 0.657 & $\begin{array}{r}0.230 \\
-0.904\end{array}$ & 62.5 \\
\hline Bap/Bghip & $0.9-6.6$ & 1.702 & $\begin{array}{r}0.065 \\
-6.856\end{array}$ & 62.5 & 0.994 & $\begin{array}{r}0.292 \\
-1.592\end{array}$ & 66.7 \\
\hline HMW/LMW & $>1$ & 1.952 & $\begin{array}{r}0.955 \\
-3.844\end{array}$ & 97.0 & 1.754 & $\begin{array}{r}0.277 \\
-4.031\end{array}$ & 60.0 \\
\hline
\end{tabular}

major sources of PAHs in the rice, hull, and mollusk samples. The source apportionment of PAHs by diagnostic ratios further confirmed the result of PCA as described above.

Compositional differences of $\mathrm{HCH}$ isomers and DDT metabolites in environmental samples have been widely used to know or find potential contamination sources (Doong et al. 2002). HCHs are usually used as two formulations. One is technical $\mathrm{HCH}$ that is a mixture of $55-80 \% \alpha-, 5-14 \% \beta-, 8-15 \% \gamma-$, and $2-16 \% \delta$-isomers (Yang et al. 2005). The other is lindane, which contains approximately $99 \%$ of $\gamma$ $\mathrm{HCH}$ (the $\mathrm{HCH}$ isomer of highest pesticide activity). Although the government has banned production of HCHs since 1983, lindane has still being used in lower amounts to control certain insects in China (UNEP Regional Report 2002). In this study, $\gamma-\mathrm{HCH}$ was frequently detected with a rate of $74 \%$ as mentioned above and few other $\mathrm{HCH}$ isomers were found with the detection rates of 7.0, 9.3, and $2.3 \%$ for $\alpha-, \beta$-, and $\delta$ isomers, respectively (Table 1). These results suggest that there is no recent application of technical HCHs, while lindane may still be used in Taizhou region, which would impact the ecosystems for years to come.

Technical DDT generally contains $75 \% p, p^{\prime}-$ DDT, $15 \% o, p^{\prime}$-DDT, $5 \% p, p^{\prime}$-DDE, and less than $5 \%$ others (Yang et al. 2007). DDT degrades to DDE and DDD under environmental conditions, and comparison of the concentrations of DDT with its metabolites can identify whether the DDT input is recent or not (Doong et al. 2002). In the present study, the DDD $\left(o, p^{\prime}\right.$-DDD and $p, p^{\prime}$-DDD) was commonly found with a detection rate of $48 \%$ and ranged $0.52-567 \mathrm{ng} / \mathrm{g}$ (mean: $35.0 \mathrm{ng} / \mathrm{g}$ ), accounting for $66 \%$ of the $\sum$ DDTs (Table 1$)$. Few DDT $\left(o, p^{\prime}\right.$-DDT and $p, p^{\prime}$ DDT) was detected with a rate of $35 \%$ and ranged $0.57-273 \mathrm{ng} / \mathrm{g}$ (mean: $27.8 \mathrm{ng} / \mathrm{g}$ ), accounting for
$30 \%$ of the $\sum$ DDTs. Only one $o, p^{\prime}$-DDE and one $p, p^{\prime}$-DDE were detected with a mean of $15.1 \mathrm{ng} / \mathrm{g}$, accounting for $4.1 \%$ of the $\sum$ DDTs. A ratio of $(\mathrm{DDE}+\mathrm{DDD}) / \sum \mathrm{DDT}>0.5$ can be deduced to result from a long-term biodegradation from DDT to DDE or DDD (Hites and Day 1992). The ratio of $(\mathrm{DDE}+\mathrm{DDD}) / \sum \mathrm{DDT}$ in this study ranged from 0.17 to 1.00 with a mean 0.70 , suggesting that the degradation occurred significantly in this area. The ratio of $\mathrm{DDT} /(\mathrm{DDE}+\mathrm{DDD})$ was in the range $0.12-4.90$ with a mean 0.91 . The ratio value was relatively high and indicated the possible fresh input of DDT in Taizhou area since the production and usage of DDT in China were officially banned in 1983 ( $\mathrm{Li}$ et al. 2005). Dicofol, an acaricide with high impurity of DDT compounds (approximate $15 \%$ ), is still being used extensively in China for the control of mites in cottons, fruit trees, and flowers and is suspected to become a new source of DDT pollution in China (Yang et al. 2008). Relative high residue levels $(36.7 \mathrm{ng} / \mathrm{g})$ and high detection rate $(51 \%)$ of dicofol in this study (Table 1) imply that parts of DDTs in rice, hull, and mollusk are possibly originated from the usage of dicofol.

\section{Dietary exposure estimates}

Based on the mean concentrations of contaminants measured in rice and mollusk samples, we estimated the daily intake (EDI; $\mu \mathrm{g} / \mathrm{kg}$ bw/day) of PAHs and OCPs through rice and mollusk consumption as shown in Eq. (1):

$\mathrm{EDI}=\frac{\sum C_{i} \times \text { Cons }_{i}}{\mathrm{BW}}$,

where $C_{i}$ is the concentration of contaminant in food $(\mu \mathrm{g} / \mathrm{g})$, Cons $_{i}$ is the daily average consumption of food 
Table 4 Estimated dietary intake ( $\mu \mathrm{g} / \mathrm{kg}$ bw/day) of PAHs and OCPs by ingestion of rice and mollusk in relation to the tolerable daily intake (TDI)

\begin{tabular}{|c|c|c|c|c|c|}
\hline Compounds & EDI_r ${ }^{a}$ & EDI_m ${ }^{\mathrm{a}}$ & EDI_t $t^{\mathrm{a}}$ & TDI China & $\%$ of TDI \\
\hline Nap & 0.046 & 0.002 & 0.049 & $20^{\mathrm{c}}$ & 0.24 \\
\hline Acpy & $0^{\mathrm{b}}$ & 0.001 & 0.001 & $-{ }^{\mathrm{d}}$ & - \\
\hline Flu & 0.017 & 0.006 & 0.023 & $40^{\mathrm{c}}$ & 0.06 \\
\hline Acp & 0.003 & 0.001 & 0.004 & $60^{\mathrm{c}}$ & 0.01 \\
\hline $\mathrm{Pa}$ & 0.053 & 0.001 & 0.055 & - & - \\
\hline Ant & 0.010 & 0.001 & 0.010 & $300^{\mathrm{c}}$ & 0.003 \\
\hline $\mathrm{Fl}$ & 0.038 & 0.003 & 0.041 & $40^{\mathrm{c}}$ & 0.10 \\
\hline Pyr & 0.042 & 0.001 & 0.043 & $30^{\mathrm{c}}$ & 0.14 \\
\hline $\mathrm{Baa}$ & 0.016 & 0.000 & 0.017 & - & - \\
\hline $\mathrm{Chr}$ & 0.022 & 0.000 & 0.022 & - & - \\
\hline $\mathrm{Bbf}$ & 0.014 & 0.001 & 0.015 & - & - \\
\hline Bkf & 0.006 & 0.001 & 0.006 & - & - \\
\hline Bap & 0.010 & 0.002 & 0.012 & - & - \\
\hline Ind & 0.027 & 0.010 & 0.037 & - & - \\
\hline Dba & 0.041 & 0 & 0.041 & - & - \\
\hline Bghip & 0.035 & 0.002 & 0.037 & - & - \\
\hline$\Sigma$ PAHs & 0.380 & 0.032 & 0.411 & - & - \\
\hline$\alpha-\mathrm{HCH}$ & 0 & 0.005 & 0.005 & - & - \\
\hline$\beta-\mathrm{HCH}$ & 0 & 0.004 & 0.004 & - & - \\
\hline$\gamma-\mathrm{HCH}$ & 0.122 & 0.007 & 0.129 & $1.0^{\mathrm{e}}$ & 12.9 \\
\hline$\delta-\mathrm{HCH}$ & 0 & 0 & 0 & - & - \\
\hline$\Sigma \mathrm{HCHs}$ & 0.122 & 0.015 & 0.137 & 2.0 & 6.87 \\
\hline$o, p^{\prime}$-DDE & 0 & 0.002 & 0.002 & - & - \\
\hline$p, p^{\prime}$-DDE & 0 & 0 & 0 & - & - \\
\hline$o, p^{\prime}$-DDD & 0.015 & 0.004 & 0.019 & - & - \\
\hline$p, p^{\prime}$-DDD & 0.009 & 0.013 & 0.021 & - & - \\
\hline$o, p^{\prime}$-DDT & 0.008 & 0.011 & 0.019 & - & - \\
\hline$p, p^{\prime}$-DDT & 0.014 & 0 & 0.014 & - & - \\
\hline$\Sigma$ DDTs & 0.046 & 0.030 & 0.076 & 10.0 & 0.76 \\
\hline Hexachlorobenzene & 0.001 & 0.000 & 0.001 & $0.27^{\mathrm{f}}$ & 0.56 \\
\hline Atrazine & 0.018 & 0.001 & 0.019 & - & - \\
\hline Quintozene & 0.020 & 0.001 & 0.021 & - & - \\
\hline Heptachlor & 0.515 & 0 & 0.515 & - & - \\
\hline Dicofol & 0.147 & 0.004 & 0.151 & - & - \\
\hline Chlorobenzilate & 0 & 0.001 & 0.001 & - & - \\
\hline$\Sigma \mathrm{OCPs}$ & 0.869 & 0.052 & 0.921 & - & - \\
\hline
\end{tabular}

a EDI_r, EDI_m, and EDI_t represent EDI by ingestion of rice, mollusk, and both, respectively

b Concentrations below LOQ were treated as 0 for EDI calculation

c US EPA's reference dose (RfD) (IPCS 1998; US EPA 1993)

d Data not available

e Acceptable daily intake (ADI)

f TDI from Health Canada (Van Oostdam et al. 2005) 
(g/day), and BW is body weight $(\mathrm{kg})$. We assumed an absorption efficiency of $100 \%$ for PAHs and OCPs from food to systemic blood circulation. Daily rice consumption data for the adult residents in this region are taken from a local dietary nutrition intake level survey, which is $323 \mathrm{~g} /$ day (Zhong et al. 2006), and daily mollusk consumption is assumed as $34.2 \mathrm{~g}$ (Meng et al. 2007). The body weight is set to $63 \mathrm{~kg}$ in this study (Zhou et al. 2012).

The mean EDI values for PAHs and OCPs from rice and mollusk are given in Table 4 . The daily intakes of Nap, Flu, Acp, Ant, Fl, and Pyr were calculated to $0.065,0.057,0.011,0.014,0.059$, and $0.049 \mu \mathrm{g} / \mathrm{kg} \mathrm{bw} / \mathrm{day}$, which were found to be considerably lower than the US EPA's reference doses (RfD; IPCS 1998; US EPA 1993). The EDIs of $\sum \mathrm{HCHs}$ and $\sum \mathrm{DDT}$ were 0.137 and $0.076 \mu \mathrm{g}$ / $\mathrm{kg}$ bw/day, corresponding to 6.9 and $0.8 \%$ of the TDIs proposed by the Chinese Government, which are 2.0 and $10.0 \mu \mathrm{g} / \mathrm{kg}$ bw/day, respectively ( $\mathrm{MOH}$ 2005). In general, the daily intakes of PAHs and OCPs from rice were one order of magnitude higher than those from mollusk, although the concentrations, on a dry weight basis, of these compounds in mollusk were higher than those in rice (Table 1). This was mainly because of (1) higher consumption of rice than mollusk (323 vs. $34.2 \mathrm{~g} / \mathrm{day}$ ); (2) higher moisture content (around $85 \%$ ) in mollusk (O'Connor 1991). The daily intakes of $\sum \mathrm{HCHs}$ and $\sum$ DDTs $(0.015$ and $0.030 \mu \mathrm{g} / \mathrm{kg}$ bw/day) from mollusk in this study were one order of magnitude higher than those $(0.001$ and $0.003 \mu \mathrm{g} / \mathrm{kg}$ bw/day) reported in Dalian, a coastal city in northeast China (Jia et al. 2010).

Rice is generally used as a staple foodstuff in China, especially in the south of China such as Zhejiang province, and rice hull is usually used to feed fowl, critter, and fish in villages in China. Mollusk is also a popular seafood for the people lived in coastal cities. Accordingly, elevated concentrations of PAHs and OCPs in rice, its hull, and mollusk can be bioaccumulated in animal products and then transferred through food chain to human eventually, which poses potent threat to the local ecosystem and human health. It should be noted that the EDI values estimated in this study may be an underestimate of actual exposures, since only two food items were taken into consideration in calculation of exposure.

\section{Conclusion}

This study describes PAH and OCP contamination in rice, its hull, and mollusks from Taizhou, a typical e-waste recycling area in southeast China. The results suggest that concentrations of PAHs and OCPs in foodstuffs, including rice and mollusks, in the tested area are moderate to high in comparison with those reported for other locations in China and some counties. Source apportionment implies that combustion of coal, wood, and plastic wastes that are closely associated with crude e-waste recycling activities is the main source of PAHs in this area. Isomer and metabolite profiles suggest a recent usage or discharge of HCH and DDT into the tested area. Contamination status for the two groups of chemicals decreased from 2005 to 2007, indicating that impact of e-waste dismantling in the tested area might be gradually alleviated. The estimated daily intake of PAHs and OCPs through rice and mollusk consumption was on the order of a few tens to several hundreds of $n g / \mathrm{kg}$ bw/day.

Acknowledgments We are grateful to the National Natural Science Foundation of China (20907039), the Department of Science and Technology of Shandong Province (BS2009HZ003), and the State Key Laboratory of Environmental Chemistry and Ecotoxicology (KF2008-19) for the financial support.

\section{References}

Chen, S. B., Shi, L. L., Shan, Z. J., \& Hu, Q. H. (2007). Determination of organochlorine pesticide residues in rice and human and fish fat by simplified two-dimensional gas chromatography. Food Chemistry, 104, 1315-1319.

Devier, M. H., Augagneur, S., Budzinski, H., Le Menach, K., Mora, P., Narbonne, J. F., et al. (2005). One-year monitoring survey of organic compounds (PAHs, PCBs, TBT), heavy metals and biomarkers in blue mussels from the Arcachon Bay, France. Journal of Environmental Monitoring, 7, 224-240.

Doong, R. A., Peng, C. K., Sun, Y. C., \& Liao, P. L. (2002). Composition and distribution of organochlorine pesticide residues in surface sediments from the Wu-Shi River estuary, Taiwan. Marine Pollution Bulletin, 45, 246-253.

Douben, P. E. T. (2003). PAH: An ecological perspective. New York: Willey.

European Commission (EC). (2002). Polycyclic aromatic hydrocarbons-Occurrence in foods, dietary exposure and health effects. 4 December 2002. http://ec.europa.eu/food/ fs/sc/scf/out154_en.pdf. Assessed December 16, 2012.

European Food Safety Authority (EFSA). (2008). Polycyclic aromatic hydrocarbons in food. Scientific opinion of the 
panel on contaminants in the food chain. 28 June 2008. http://www.efsa.europa.eu/en/efsajournal/doc/724.pdf. Assessed December 16, 2012.

Food and Agriculture Organization (FAO). (2004). FAOSTAT, FAO statistical databases. http://apps.fao.org/. Accessed July 25, 2012.

Fu, J. J., Wang, T., Wang, P., Qu, G. B., Wang, Y. W., Zhang, Q. H., et al. (2012). Temporal trends (2005-2009) of PCDD/ Fs, PCBs, PBDEs in rice hulls from an e-waste dismantling area after stricter environmental regulations. Chemosphere, 88(3), 330-335.

Fu, J. J., Zhou, Q. F., Liu, J. M., Liu, W., Wang, T., Zhang, Q. H., et al. (2008). High levels of heavy metals in rice (Oryza sativa L.) from a typical E-waste recycling area in southeast China and its potential risk to human health. Chemosphere, 71, 1269-1275.

Gao, J., Luo, Y. M., Li, Q. B., Zhang, H. B., Wu, L. H., Song, J., et al. (2006). Distribution patterns of polychlorinated biphenyls in soils collected from Zhejiang province, east China. Environmental Geochemistry and Health, 28(1-2), 79-87.

Hicks, C., Dietmar, R., \& Eugster, M. (2005). The recycling and disposal of electrical and electronic waste in ChinaLegislative and market responses. Environmental Impact Assessment Review, 25, 459-471.

Hites, R. K., \& Day, H. R. (1992). Unusual persistent of DDT in some western USA soils. Bulletin of Environmental Contamination and Toxicology, 48, 259-264.

Huo, X., Peng, L., Xu, X., Zheng, L., Qiu, B., Qi, Z., et al. (2007). Elevated blood lead levels of children in Guiyu, an electronic waste recycling town in China. Environmental Health Perspectives, 115(7), 1113-1117.

International Programme on Chemical Safety (IPCS). (1998). Environmental health criteria 202. Selected non-heterocyclic polycyclic aromatic hydrocarbons, WHO, Geneva. http://www.inchem.org/documents/ehc/ehc/ehc202.htm. Accessed August 16, 2012.

Jia, H., Chang, Y., Sun, Y., Wang, D., Liu, X., Yang, M., et al. (2010). Distribution and potential human risk of organochlorine pesticides in market mollusks from Dalian, China. Bulletin of Environmental Contamination and Toxicology, 84(3), 278-284.

Kavouras, I. G., Koutrakis, P., Tsapakis, M., Lagoudaki, E., Stephanou, E. G., Von Baer, D., et al. (2001). Source apportionment of urban particulate aliphatic and polynuclear aromatic hydrocarbons (PAHs) using multivariate methods. Environmental Science and Technology, 35(11), 2288-2294.

Khalili, N. R., Scheff, P. A., \& Holsen, T. M. (1995). PAH source fingerprints for coke ovens, diesel and gasoline engines, highway tunnels, and wood combustion emissions. Atmospheric Environment, 29, 533-542.

Larsen, R. K., \& Baker, J. E. (2003). Source apportionment of polycyclic aromatic hydrocarbons in the urban atmosphere: A comparison of three methods. Environmental Science and Technology, 37, 1873-1881.

Li, S., Frank, W., Ying, D. L., Camill, A., Derekc, G. M., \& Andterry, F. B. (2005). Atmospheric distribution and longrange transport behavior of organochlorine pesticides in North America. Environmental Science and Technology, 39, 409-420.
Li, H., Yu, L., Sheng, G., Fu, J., \& Peng, P. (2007). Severe $\mathrm{PCDD} / \mathrm{F}$ and $\mathrm{PBDD} / \mathrm{F}$ pollution in air around an electronic waste dismantling area in China. Environmental Science and Technology, 41, 5641-5646.

Liao, C., Lv, J., Fu, J., Zhao, Z., Liu, F., Xue, Q., et al. (2012). Occurrence and profiles of polycyclic aromatic hydrocarbons (PAHs), polychlorinated biphenyls (PCBs) and organochlorine pesticides (OCPs) in soils from a typical $\mathrm{e}$-waste recycling area in Southeast China. International Journal of Environmental Health Research, 22(4), 317-330.

Liu, G., Niu, Z., Van Niekerk, D., Xue, J., \& Zheng, L. (2008a). Polycyclic aromatic hydrocarbons (PAHs) from coal combustion: Emissions, analysis, and toxicology. Reviews of Environmental Contamination and Toxicology, 192, $1-28$.

Liu, H. X., Zhou, Q. F., Wang, Y. W., Zhang, Q. H., Cai, Z. W., \& Jiang, G. B. (2008b). E-waste recycling induced polybrominated diphenyl ethers, polychlorinated biphenyls, polychlorinated dibenzo-p-dioxins and dibenzo-furans pollution in the ambient environment. Environment International, 34, 67-72.

Ma, J., Horii, Y., Cheng, J., Wang, W., Wu, Q., Ohura, T., et al. (2009). Chlorinated and parent polycyclic aromatic hydrocarbons in environmental samples from an electronic waste recycling facility and a chemical industrial complex in China. Environmental Science and Technology, 43(3), 643-649.

Meng, X. Z., Zeng, E. Y., Yu, L. P., Mai, B. X., Luo, X. J., \& Ran, Y. (2007). Persistent halogenated hydrocarbons in consumer fish of China: Regional and global implications for human exposure. Environmental Science and Technology, 41(6), 1821-1827.

Ministry of Health (MOH). (2005). GB2763-2005. http://www. moh.gov.cn/publicfiles//business/htmlfiles/zwgkzt/pwsbz/ index.htm. Accessed August 16, 2012.

Nakata, H., Kawazoe, M., Arizono, K., Abe, S., Kitano, T., Shimada, H., et al. (2002). Organochlorine pesticides and polychlorinated biphenyls residues in foodstuffs and human tissues from China: Status of concentration, historical trends, and human dietary exposure. Archives of Environmental Contamination and Toxicology, 43(4), 473-480.

O'Connor, T. P. (1991). Concentrations of organic contaminants in mollusks and sediments at NOAA National Status and Trend sites in the coastal and estuarine United States. Environmental Health Perspectives, 90, 69-73.

Osibanjo, O., \& Nnorom, I. C. (2007). The challenge of electronic waste (e-waste) management in developing countries. Waste Management and Research, 25, 489-501.

Perelló, G., Martí-Cid, R., Castell, V., Llobet, J. M., \& Domingo, J. L. (2009). Concentrations of polybrominated diphenyl ethers, hexachlorobenzene and polycyclic aromatic hydrocarbons in various foodstuffs before and after cooking. Food and Chemical Toxicology, 47, 709-715.

Qi, Z. Y., Ma, X. T., Wang, Z. R., Lin, G. Y., Xu, F. X., \& Dong, Z. Z. (1989). Mollusca of Huanghai and Bohai Sea. Beijingx: Agriculture Publishing House. (in Chinese).

Robinson, B. H. (2009). E-waste: An assessment of global production and environmental impacts. Science of the Total Environment, 408(2), 183-191. 
Shen, C., Chen, Y., Huang, S., Wang, Z., Yu, C., Qiao, M., et al. (2009). Dioxin-like compounds in agricultural soils near e-waste recycling sites from Taizhou area, China: Chemical and bioanalytical characterization. Environment International, 35(1), 50-55.

Skarphedinsdottir, H., Gunnarsson, K., Gudmundsson, G. A., \& Nfon, E. (2010). Bioaccumulation and biomagnification of organochlorines in a marine food web at a pristine site in Iceland. Archives of Environmental Contamination and Toxicology, 58, 800-809.

Soclo, H. H., Garrigues, P., \& Ewald, M. (2000). Origin of polycyclic aromatic hydrocarbons (PAHs) in coastal marine sediments: Case studies in Cotonou (Benin) and Aquitaine (France) areas. Marine Pollution Bulletin, 40, 387-396.

Song, Y., Wu, N., Han, J., Shen, H., Tan, Y., Ding, G., et al. (2011). Levels of PCDD/Fs and DL-PCBs in selected foods and estimated dietary intake for the local residents of Luqiao and Yuhang in Zhejiang, China. Chemosphere, 85(3), 329-334.

Sundar, G., Selvarani, J., Gopalakrishnan, S., \& Ramachandran, S. (2010). Occurrence of organochlorine pesticide residues in green mussel (Perna viridis L.) and water from Ennore creek, Chennai. India. Environmental Monitoring and Assessment, 160, 593-604.

Tao, S., Jiao, X. C., Chen, S. H., Liu, W. X., Coveney, R. M., Jr, Zhu, L. Z., et al. (2006). Accumulation and distribution of polycyclic aromatic hydrocarbons in rice (Oryza sativa). Environmental Pollution, 140(3), 406-415.

Tao, S., Liu, W., Li, Y., Yang, Y., Zuo, Q., Li, B., et al. (2008). Organochlorine pesticides contaminated surface soil as reemission source in the Haihe Plain, China. Environmental Science and Technology, 42(22), 8395-8400.

United Nations Environment Programme (UNEP). (2002). Central and North East Asia Regional Report. Regionally based assessment of persistent toxic substances. Chatelaine, Switzerland: UNEP Chemicals, 2002. http://www. chem.unep.ch/pts/regreports/C\&NE\%20Asia\%20full\%20 report.pdf. Assessed September 10, 2012.

United States Environmental Protection Agency (US EPA). (1993). Provisional guidance for quantitative risk assessment of PAH. EPA/600/R-93/089.

Van Oostdam, J., Donaldson, S. G., Feeley, M., Arnold, D., Ayotte, P., Bondy, G., et al. (2005). Human health implications of environmental contaminants in Arctic Canada: A review. Science of the Total Environment, 351-352, 165-246.

Wong, C. S., Wu, S. C., Duzgoren-Aydin, N. S., Aydin, A., \& Wong, M. H. (2007). Trace metal contamination of sediments in an e-waste processing village in China. Environmental Pollution, 145, 434-442.

Xing, G. H., Wu, S. C., \& Wong, M. H. (2010). Dietary exposure to PCBs based on food consumption survey and food basket analysis at Taizhou, China-The World's major site for recycling transformers. Chemosphere, 81(10), 1239-1244.

Yang, R. Q., Jiang, G. B., Zhou, Q. F., Yuan, C. G., \& Shi, J. B. (2005). Occurrence and distribution of organochlorine pesticides (HCH and DDT) in sediments collected from East China Sea. Environment International, 31, 799-804.

Yang, X., Wang, S., Bian, Y., Chen, F., Yu, G., Gu, C., et al. (2008). Dicofol application resulted in high DDTs residue in cotton fields from northern Jiangsu province. China. Journal of Hazardous Materials, 150(1), 92-98.

Yang, R. Q., Yao, T. D., Xu, B. Q., Jiang, G. B., \& Xin, X. D. (2007). Accumulation features of organochlorine pesticides and heavy metals in fish from high mountain lakes and Lhasa River in the Tibetan Plateau. Environment International, 33, 151-156.

Yu, X. Z., Gao, Y., Wu, S. C., Zhang, H. B., Cheung, K. C., \& Wong, M. H. (2006). Distribution of polycyclic aromatic hydrocarbons in soils at Guiyu area of China, affected by recycling of electronic waste using primitive technologies. Chemosphere, 65, 1500-1509.

Yunker, M. B., Macdonald, R. W., Vingarzan, R., Mitchell, H. R., Goyette, D., \& Sylvestre, S. (2002). PAHs in the Fraser River basin: A critical appraisal of PAH ratios as indicators of PAH source and composition. Organic Geochemistry, 33, 489-515.

Zhao, K., Liu, X., Zhang, W., Xu, J., \& Wang, F. (2011). Spatial dependence and bioavailability of metal fractions in paddy fields on metal concentrations in rice grain at a regional scale. Journal of Soils and Sediments, 11(7), 1165-1177.

Zhao, G., Xu, Y., Han, G., \& Ling, B. (2007). PCBs and OCPs in human milk and selected foods from Luqiao and Pingqiao in Zhejiang, China. Science of the Total Environment, 378, 281-292.

Zhao, G., Zhou, H., \& Wang, Z. (2010). Concentrations of selected heavy metals in food from four e-waste disassembly localities and daily intake by local residents. Journal of Environmental Science and Health, Part A: Toxic/Hazardous Substances and Environmental Engineering, 45(7), 824-835.

Zhao, G., Zhou, H., Wang, D., Zha, J., Xu, Y., Rao, K., et al. (2009). PBBs, PBDEs, and PCBs in foods collected from e-waste disassembly sites and daily intake by local residents. Science of the Total Environment, 407(8), 2565-2575.

Zhong, J., Yu, M., Liu, L., Chen, Y., Hu, R., \& Gong, W. (2006). Study on the dietary nutrition intake level in Zhejiang Province. Disease Surveillance, 21(12), 670-672. (in Chinese).

Zhou, P., Zhao, Y., Li, J., Wu, G., Zhang, L., Liu, Q., et al. (2012). Dietary exposure to persistent organochlorine pesticides in 2007 Chinese total diet study. Environment International, 42, 152-159. 